\title{
Migration diversity of the freshwater goby Rhinogobius sp. BI, as revealed by otolith Sr:Ca ratios
}

\author{
Takatoshi Tsunagawa ${ }^{1}$, Takaomi Arai $^{2, *}$ \\ ${ }^{1}$ Laboratory of Ecophysiology, Graduate School of Fisheries Sciences, Kitasato University, 160-4 Sanriku, Ofunato, \\ Iwate 022-0101, Japan \\ ${ }^{2}$ International Coastal Research Center, Ocean Research Institute, The University of Tokyo, 2-106-1 Akahama, Otsuchi, \\ Iwate 028-1102, Japan
}

\begin{abstract}
The migratory histories of the endangered freshwater goby Rhinogobius sp. BI (Bonin Island type) collected from 6 stations on Chichijima Island, part of the Bonin Islands chain in Japan, were studied by examining the environmental signatures of strontium and calcium concentrations in otoliths using electron probe microanalyses. The Sr:Ca ratios in the otoliths showed when the gobies had experienced various salinity environments such as freshwater, brackish water, and seawater. The otolith Sr:Ca ratios of almost all Rhinogobius sp. BI from rivers connected to the sea reflected the typical amphidromous life history. In contrast, fish collected upriver from a dam, disconnected from the downstream area, utilized freshwater habitats only, reflecting an artificially landlocked life history. Further flexible migration patterns were found in fish from areas downstream of the aforementioned dam (in a river connected to the sea), indicating that they utilized freshwater, brackish water, and seawater in their larval and adult life period. The present study clearly suggests that the migratory histories of Rhinogobius sp. BI are highly variable within habitats and that they have flexible migratory patterns, allowing them to utilize the full range of salinity during their life history.
\end{abstract}

KEY WORDS: Rhinogobius · Endangered species $\cdot$ Bonin Islands · Otolith Sr:Ca ratios $\cdot$ Flexible migration

Resale or republication not permitted without written consent of the publisher

\section{INTRODUCTION}

Freshwater gobies, genus Rhinogobius (Pisces: Gobiidae), are widely distributed in East Asian countries, as far north as the Russian Amur River system and as far south as Mindanao Island, Philippines (Aonuma et al. 1998, Senou et al. 2004). In Japan, these fishes are also distributed widely from Hokkaido Island to the Ryukyu Archipelago, and more than 13 species have been reported; however, most of them remain taxonomically uncertain, although reproductive isolation among Japanese Rhinogobius species has been confirmed by both partner selection experiments and isozyme analyses (Mizuno et al. 2001, Senou et al. 2004). Therefore, their scientific name has not yet been decided and only common names have been given on the basis of the colour of macules and morphological features (Mizuno et al. 2001).

The Bonin (Ogasawara) Islands consist of the small oceanic islands, Chichijima, Anijima, Hahajima, and the Mukojima Islands, located in the northwestern Pacific about $1000 \mathrm{~km}$ south of metropolitan Tokyo, Japan. These islands have never been connected by land to the continent since the time of their origin. Rhinogobius sp. BI (Bonin Island type) is an endemic freshwater goby distributed in the Chichijima, Anijima, and Hahajima Islands (Suzuki 1992, 2003, Akihito et al. 2000, Mizuno et al. 2001, Yokoi \& Hosoya 2003, 2006). This species is designated an endangered species (Ministry of the Environment of Japan 2003) because of habitat disappearance caused by artificial river improvement, deforestation, and topsoil erosion, 
which continues even now (Suzuki 2003). Therefore, it is essential to take practical measures to protect the natural populations of this goby (Iwata 1997, Yokoi \& Hosoya 2003, 2006). Ecological information about this goby is vital to implementing effective protective measures. In general, the life history patterns of the Rhinogobius species have been divided into 3 categories: amphidromous, fluvial and lacustrine (Mizuno et al. 2001). However, the migration history of the Rhinogobius sp. BI is still largely unknown.

Recent chemical analytical techniques have enabled the identification of life history events in individual fishes by detecting trace elements in the microstructure of their otoliths (Campana 1999, Arai 2002). Strontium (Sr) incorporation in fish otoliths is of special interest because of its potential utility as an indicator of past environmental (temperature and salinity) and physiological (ontogenetic change) conditions (Campana 1999). The deposition of $\mathrm{Sr}$ and calcium ( $\mathrm{Ca}$ ) in fish otoliths during their growth varies between freshwater and marine habitats (Campana 1999). Sr concentrations are 1 to 2 orders of magnitude higher in seawater than in freshwater (Campana 1999). Factors other than salinity have been shown to affect Sr deposition rates, including temperature, growth, developmental or reproductive stage, genetics, and diet (Campana 1999). These factors, unlike the salin- ity effect, have not been systematically linked to the fluctuation of otolith Sr:Ca ratios. Although the values of the $\mathrm{Sr}$ :Ca ratios in otoliths are highly variable among species, ambient salinity is positively related to the $\mathrm{Sr}$ :Ca ratios of almost all fish species studied (Secor \& Rooker 2000). Recently, Tsunagawa \& Arai (2008) have found that otolith $\mathrm{Sr}$ :Ca ratios were positively related to ambient water salinity in Rhinogobius species. Therefore, this technique can be applied to reveal the migratory patterns of Rhinogobius sp. BI.

The objectives of the present study were to provide life history information by examining $\mathrm{Sr}$ :Ca ratios in the otoliths of the endangered freshwater goby Rhinogobius sp. BI. The results provide a basis for a discussion of the life history of this endangered species as well as information which should prove useful for attempts to protect them.

\section{MATERIALS AND METHODS}

Fish. The samples of Rhinogobius sp. BI used in the present study were collected from 6 stations in the Yatsuse River and the Sakaiura River on Chichijima Island, one of the Bonin Islands, Japan, from June 6 to 9, 2008, using dip nets (Fig. 1, Table 1). Sampling

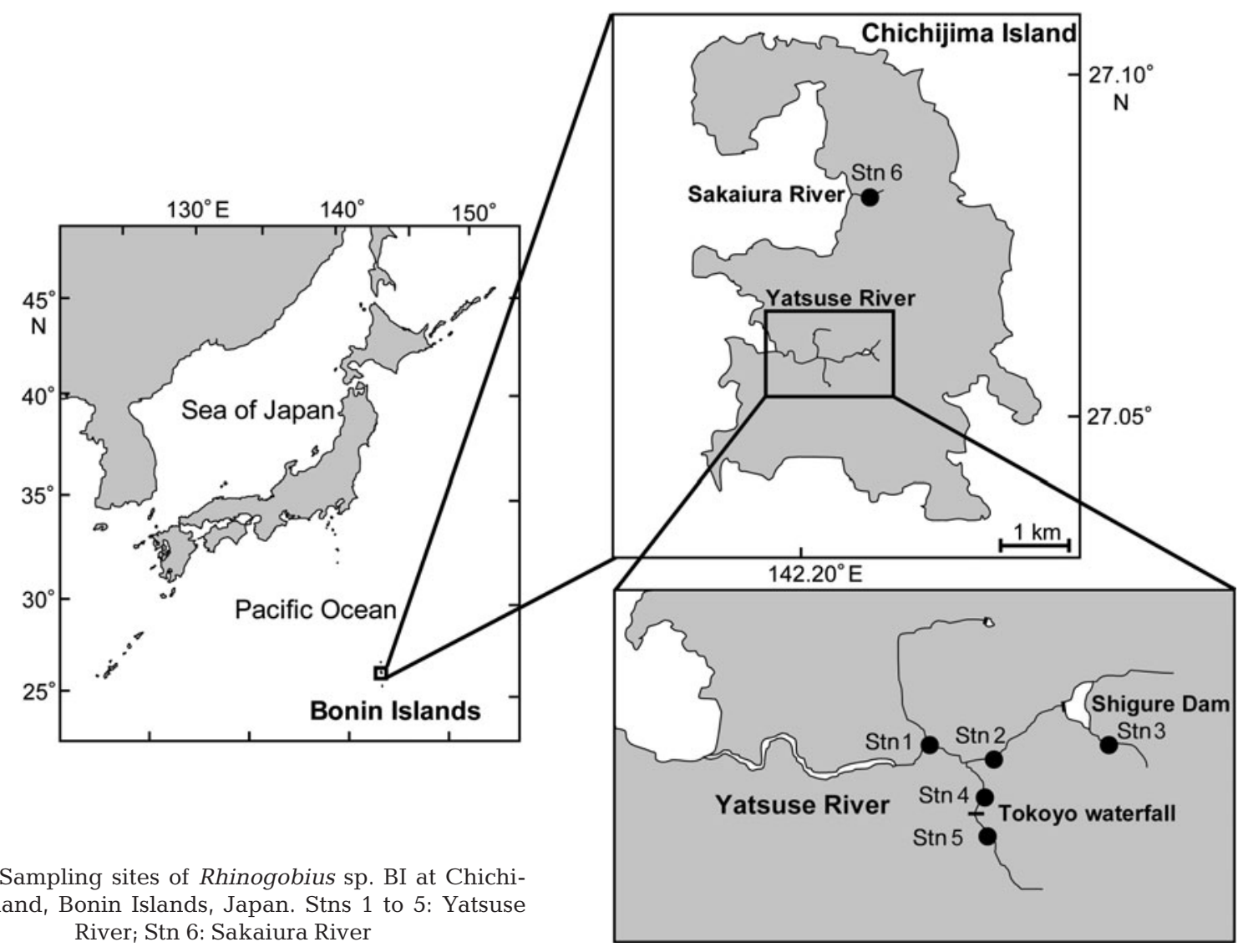

Fig. 1. Sampling sites of Rhinogobius sp. BI at Chichijima Island, Bonin Islands, Japan. Stns 1 to 5: Yatsuse River; Stn 6: Sakaiura River 
Table 1. Rhinogobius sp. BI. Specimens used for otolith microchemistry analyses

\begin{tabular}{|c|c|c|c|c|c|}
\hline Stn & $\begin{array}{l}\text { Sampling } \\
\text { location }\end{array}$ & $\begin{array}{l}\text { Sampling } \\
\text { date }\end{array}$ & $\begin{array}{c}\text { No. of } \\
\text { fish examined }\end{array}$ & $\begin{array}{c}\text { Standard } \\
\text { length }(\mathrm{mm})\end{array}$ & $\begin{array}{l}\text { Migration pattern estimated } \\
\text { from Sr:Ca ratios }\end{array}$ \\
\hline 1 & Yatsuse River & 7 June 2008 & 10 & $27.98-64.43$ & $\begin{array}{l}\text { Typical amphidromous } \\
\text { Long marine phase amphidromous } \\
\text { Multiple inter-habitat amphidromous } \\
\text { Short brackish water phase amphidromous }\end{array}$ \\
\hline 2 & Yatsuse River & 6 June 2008 & 10 & $27.59-44.57$ & $\begin{array}{l}\text { Typical amphidromous } \\
\text { Long marine phase amphidromous } \\
\text { Artificially or naturally landlocked }\end{array}$ \\
\hline 3 & $\begin{array}{l}\text { Yatsuse River } \\
\text { (upriver of Shigure Dam) }\end{array}$ & 6 June 2008 & 5 & $29.21-42.08$ & Artificially landlocked \\
\hline 4 & $\begin{array}{l}\text { Yatsuse River } \\
\text { (basin of Tokoyo waterfall) }\end{array}$ & 7 June 2008 & 10 & $30.60-42.35$ & Typical amphidromous \\
\hline 5 & $\begin{array}{l}\text { Yatsuse River } \\
\text { (upstream of Tokoyo } \\
\text { waterfall) }\end{array}$ & 7 June 2008 & 5 & $36.24-44.71$ & $\begin{array}{l}\text { Typical amphidromous } \\
\text { Short brackish water phase amphidromous }\end{array}$ \\
\hline 6 & Sakaiura River & 9 June 2008 & 5 & $17.53-46.58$ & Typical amphidromous \\
\hline
\end{tabular}

Stns 1 and 2 are in the main river in the Yatsuse River. There are no obstructions preventing fish from migrating either downstream to the sea or upstream from the sea via the river. Stn 3 is upriver from the Shigure Dam in the Yatsuse River. The dam wall is about $24 \mathrm{~m}$ tall and completely divides the river, thus preventing upstream migration, although it is thought that downstream migration is possible. Stns 4 and 5 are a basin and a section of river above the Tokoyo waterfall (respectively) in a tributary of the Yatsuse River. The height of the waterfall is about $20 \mathrm{~m}$; therefore, upstream migration to Stn 5 is thought to be impossible, although migration from both stations to the sea is possible. Stn 6 is located in the Sakaiura River, which is connected to the sea without obstructions to upstream or downstream migration. All samples were collected from freshwater areas, with no influence from the rising tide and showed $0 \%$ salinity. After collection, all specimens were anesthetized, and thereafter fixed immediately by freezing. A total of 45 specimens were used for otolith microchemical analyses (Table 1).

Otolith preparation and otolith X-ray microprobe analyses. Sagittal otoliths were extracted from each fish, embedded in epoxy resin (Struers, Epofix), and mounted on glass slides after measuring the standard length of each fish. The otoliths were then ground to expose the core, using a grinding machine equipped with a diamond cup wheel (Struers, Discoplan-TS), and polished further with oxide polishing suspension on an automated polishing wheel (Struers, PdM-Force20). Finally, they were cleaned in an ultrasonic bath and rinsed with deionized water prior to examination.

For electron microprobe analyses, all otoliths were platinum-palladium (Pt-Pd) coated by a high vacuum evaporator. Otoliths from all specimens were used for life history transect analyses of the $\mathrm{Sr}$ and $\mathrm{Ca}$ concentrations, which were measured along a line down the longest axis of each otolith from the core to the edge using a wavelength dispersive X-ray electron microprobe (JEOL JXA-8900R), as described in Arai et al. (1997). Wollastonite (CaSiO3) and Tausonite (SrTiO3) were used as standards. The accelerating voltage and beam current were $15 \mathrm{kV}$ and $1.2 \times 10^{-8} \mathrm{~A}$, respectively. The electron beam was focused on a point $5 \mu \mathrm{m}$ in diameter, with measurements spaced at $5 \mu \mathrm{m}$ intervals.

$\mathrm{X}$-ray intensity maps of $\mathrm{Sr}$ and $\mathrm{Ca}$ were made using JEOL JXA-8900R as described by Arai et al. (2004) and Goto \& Arai (2003). The beam current was $0.5 \mu \mathrm{A}$, counting time was $0.1 \mathrm{~s}$ and pixel size was $2 \times 2 \mu \mathrm{m}$. The electron beam was focused on a point $1 \mu \mathrm{m}$ in diameter, and the other analytical conditions followed those for the life history transect analyses.

Statistical analyses. Statistical analyses were performed using Systat (Systat Software). Differences among data of mean Sr:Ca ratios in otolith were tested by repeated measures ANOVA and $t$-test, and overall differences between groups were assessed using its methods.

\section{RESULTS}

\section{Otolith $\mathrm{Sr}$ distribution}

X-ray intensity maps showed that the otolith Sr concentrations were remarkably variable among the Rhinogobius sp. BI examined (Fig. 2). Thirty-two samples from Stns $1(\mathrm{n}=6), 2(\mathrm{n}=7), 4(\mathrm{n}=10)$, and 5 $(\mathrm{n}=4)$ in the Yatsuse River and $\operatorname{Stn} 6(\mathrm{n}=5)$ in the Sakaiura River showed up as wide spaces of greenish 


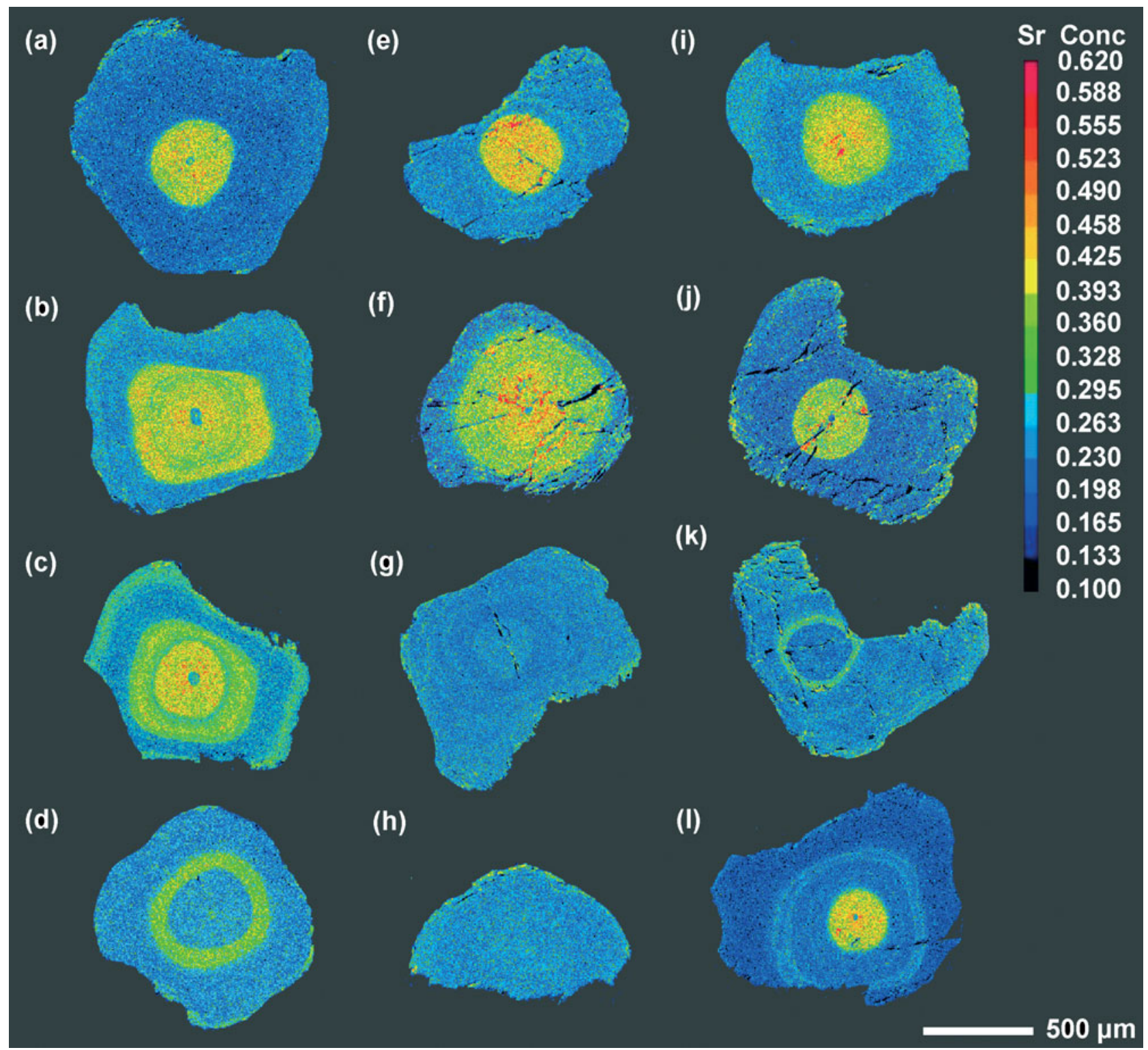

Fig. 2. Rhinogobius sp. BI. Two-dimensional imaging using X-ray electron microprobe analyses of the Sr concentration in the sagittal plane of the sagittal otolith samples from (a-d) Stn 1, (e-g) Stn 2, (h) Stn 3, (i) Stn 4, (j, k) Stn 5, and (l) Stn 6. See Fig. 1 \& Table 1 for station locations. Values corresponding to Sr concentration are represented by 16 colours from red (highest) to yellow to green to black (lowest)

yellow, yellow and orange (high Sr) surrounded by blue and light blue (low Sr), except for the lowest otolith centre (Fig. 2a,e,i,j,1). A similar pattern of Sr concentration was found in 3 samples from Stns 1 $(\mathrm{n}=2)$ and $2(\mathrm{n}=1)$, indicating high $\mathrm{Sr}$ values around the core of the otoliths. However, the high-Sr regions were larger than those of the samples described above (Fig. 2b,f). One sample from Stn 1 featured concentric rings of yellow or orange (high $\mathrm{Sr}$ ) and yellowish-green or green (medium $\mathrm{Sr}$ ) surrounding the blue (low $\mathrm{Sr}$ ) area in the otolith core. These high, medium and low $\mathrm{Sr}$ regions were surrounded by a wide space of blue and light blue (low Sr) and a narrow space of green (medium Sr) (Fig. 2c). Five samples collected from Stn 3 showed a uniformly low concentration all over the otolith (blue and light blue; Fig. 2h). A similar consistently low concentration throughout the otolith was also found in 2 samples from Stn 2 (Fig. 2g). Two samples from Stns $1(\mathrm{n}=1)$ and $5(\mathrm{n}=1)$ featured a wide band of blue and light blue (low $\mathrm{Sr}$ ) in the otolith core region surrounded by a narrow band of yellowish-green and green (medium Sr). Moreover, these regions were surrounded by blue and light blue areas (Fig. 2d,k). 


\section{Life history transects}

The Sr:Ca ratios measured along a transect from the centre to the otolith edge of Rhinogobius sp. BI of all samples $(n=5)$ collected at Stn 3 showed consistently low ratios of $2.18 \times 10^{-3} \pm 0.95 \times 10^{-3}$ (mean $\left.\pm \mathrm{SD}\right)$ (Fig. 3h). The same Sr:Ca ratio fluctuations were found in the 2 samples from Stn 2, which were uniformly low throughout the otolith $\left(2.11 \times 10^{-3} \pm 0.99 \times 10^{-3}\right)$ (Fig. 3g).

In contrast, the otolith $\mathrm{Sr}: \mathrm{Ca}$ ratios of 32 samples from Stns $1(\mathrm{n}=6), 2(\mathrm{n}=7), 4(\mathrm{n}=10)$ and $5(\mathrm{n}=4)$ in the Yatsuse River (Fig. 3a,e,i,j, respectively) and Stn 6 (n = 5) (Fig. 3l) in the Sakaiura River had low Sr:Ca ratios in 2 regions, one from the core to between 5 and $30 \mu \mathrm{m}$ (with mean values ranging from $2.38 \times 10^{-3}$ to $3.27 \times 10^{-3}$ ) and the other from between 150 and 245 $\mu \mathrm{m}$ to the edge (with mean values ranging from $1.17 \times$ $10^{-3}$ to $2.55 \times 10^{-3}$ ). The $\mathrm{Sr}: \mathrm{Ca}$ ratios from these samples were significantly higher in the wide area between the other regions (with mean values ranging from $5.92 \times 10^{-3}$ to $6.70 \times 10^{-3}$ ) (repeated measures ANOVA, $\mathrm{p}<0.0001$ for both regions).

A similar fluctuation of $\mathrm{Sr}$ : Ca ratios was found in 3 samples collected from Stn $1(\mathrm{n}=2)$ (Fig. 3b) and Stn 2 $(\mathrm{n}=1)$ (Fig. 3f). The samples had low Sr:Ca ratios in 2 regions, from the core to between 15 and $30 \mu \mathrm{m}$ (with mean values ranging from $2.16 \times 10^{-3}$ to $3.50 \times 10^{-3}$ ) and from between 310 and $350 \mu \mathrm{m}$ to the edge (with mean values ranging from $1.91 \times 10^{-3}$ to $2.35 \times 10^{-3}$ ) $\mathrm{Sr}$ :Ca ratios in these samples were significantly higher in the wide area between the other regions (with mean values ranging from $5.79 \times 10^{-3}$ to $6.25 \times 10^{-3}$ ) (repeated measures ANOVA, $p<0.0005$ for the former region, $\mathrm{p}<0.0001$ for the latter region). The high $\mathrm{Sr}: \mathrm{Ca}$ region near the otolith core of these samples was wider than that of the samples described in the previous paragraph.

One sample from Stn 1 (Fig. 3d) showed low Sr:Ca ratios in 2 regions, from the core to $175 \mu \mathrm{m}\left(2.35 \times 10^{-3} \pm\right.$ $\left.0.90 \times 10^{-3}\right)$ and from $280 \mu \mathrm{m}$ to the edge $\left(1.86 \times 10^{-3} \pm\right.$ $\left.0.87 \times 10^{-3}\right)$, with significantly higher $\mathrm{Sr}: \mathrm{Ca}$ ratios in the narrow area between the other regions $\left(4.65 \times 10^{-3} \pm\right.$ $1.45 \times 10^{-3}$ ) (repeated measures ANOVA, $\mathrm{p}<0.0001$ for both regions). The same patterns were found in 1 sample from Stn 5 (Fig. 3k), with low Sr:Ca ratios from the core to $165 \mu \mathrm{m}\left(2.24 \times 10^{-3} \pm 0.94 \times 10^{-3}\right)$ and from $265 \mu \mathrm{m}$ to the edge $\left(2.77 \times 10^{-3} \pm 1.01 \times 10^{-3}\right)$, and significantly higher ratios in the narrow area between the other regions $\left(3.98 \times 10^{-3} \pm 1.30 \times 10^{-3}\right)$ (repeated measures ANOVA, $\mathrm{p}<0.0001$ for both regions).

One sample collected from Stn 1 (Fig. 3c) showed low $\mathrm{Sr}$ :Ca ratios in 2 regions, from the core to $20 \mu \mathrm{m}$ $\left(2.74 \times 10^{-3} \pm 0.78 \times 10^{-3}\right)$ and from 340 to $480 \mu \mathrm{m}$ $\left(2.21 \times 10^{-3} \pm 0.84 \times 10^{-3}\right)$. High Sr:Ca ratios were found in the wide area around the otolith core region and the otolith edge. The former high ratio area was divided into 2 different values, from 25 to $170 \mu \mathrm{m}\left(7.31 \times 10^{-3} \pm\right.$ $\left.1.78 \times 10^{-3}\right)$ and from 175 to $335 \mu \mathrm{m}\left(5.05 \times 10^{-3} \pm\right.$ $1.28 \times 10^{-3}$ ). The latter high $\mathrm{Sr}: \mathrm{Ca}$ ratio area in the otolith edge showed $3.61 \times 10^{-3} \pm 0.95 \times 10^{-3}$ from $485 \mu \mathrm{m}$ to the edge. The $\mathrm{Sr}$ : Ca ratios of these 3 high value regions and the 2 low value regions were compared with all contrasts to estimate the environmental habitat use. The 3 high value regions are different from each combination ( $t$-test, $\mathrm{p}<0.0001)$. Moreover, these phases are remarkably higher than the 2 low ratio phases ( $t$-test, $\mathrm{p}<0.0001$ to 0.05 ). Based on difference of the $\mathrm{Sr}: \mathrm{Ca}$ ratios in these results, habitat environment were distinguished as follows: freshwater (Sr:Ca ratios $<3.5 \times 10^{-3}$ ), brackish water (Sr:Ca ratios 3.5 to $5.5 \times 10^{-3}$ ) and seawater ( $\mathrm{Sr}$ :Ca ratios $>5.5 \times 10^{-3}$ ).

\section{DISCUSSION}

In the present study, the $\mathrm{Sr}$ contents or $\mathrm{Sr}$ :Ca ratios from the life history transects taken from otoliths were remarkably different among Rhinogobius sp. BI from each site. The Sr contents in the otoliths of teleost fishes were positively correlated with ambient salinity and the deposition of $\mathrm{Sr}$ and $\mathrm{Ca}$ in the fish otoliths during growth varied among freshwater, brackish water, and seawater environments (Secor et al. 1995, Arai et al. 2004). The Sr:Ca ratios of all fish collected from above the dam were consistently low, while nearly all fish from rivers connected to the sea had areas with high Sr:Ca ratios around their otolith cores, indicating that these fish moved downstream (toward the sea) over the course of their lives. Thus, the difference of $\mathrm{Sr}$ content in the Rhinogobius sp. BI otoliths was probably due to salinity effects. Besides salinity, temperature may also affect Sr:Ca ratios in fish otoliths (Kalish 1989, Secor et al. 1995, Arai 2002). Although the effect of temperature cannot be ruled out in the present study, there is little evidence that temperature was a major factor, as all specimens from each site had been subjected to similar temperature changes. In the Yatsuse River, the mean water temperature is about $26^{\circ} \mathrm{C}$ in the summer and about $18^{\circ} \mathrm{C}$ in the winter. However, no seasonal temperature effects were found in otoliths, probably because the fluctuations of the $\mathrm{Sr}$ :Ca ratios in fishes collected upriver from the dam showed constantly low values throughout their whole life. Therefore, the most important factor influencing the Sr content or Sr:Ca ratios in the otoliths of Rhinogobius sp. BI is probably ambient salinity changes.

Most specimens collected from below the dam in the Yatsuse River, which was connected to the sea, showed a typical amphidromous life history. This 

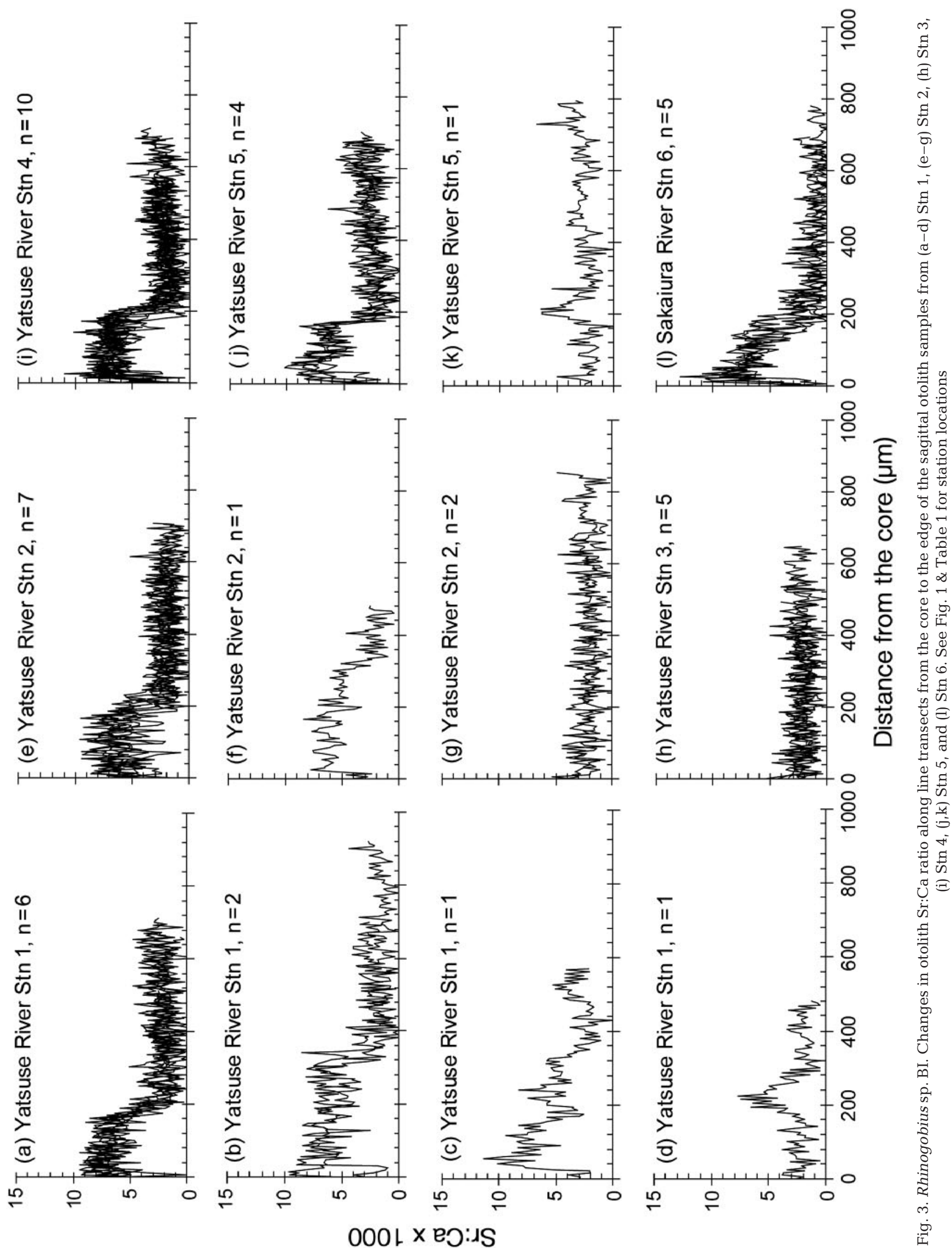


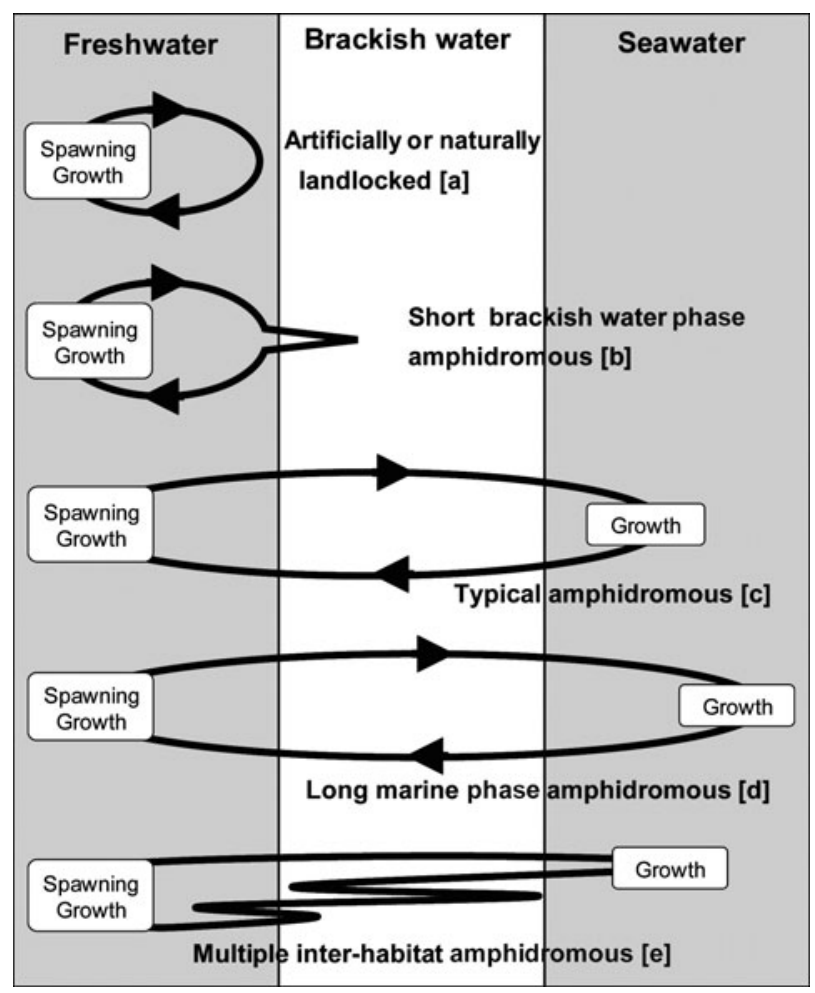

Fig. 4. Rhinogobius sp. BI. Life cycle, with special reference to migratory types as revealed by the otolith $\mathrm{Sr}$ :Ca ratio analyses along the life history transect. (a) Artificially or naturally landlocked type, (b) short brackish water phase amphidromous type, (c) typical amphidromous type, (d) long marine phase amphidromous type, (e) multiple inter-habitat amphidromous type

pattern was also found in all specimens from the Sakaiura River. As is common in freshwater goby with amphidromous life cycles (McDowall 1992, 1997), these fish drift to the sea just after hatching in a freshwater environment and spend their early lives in the sea for growth, thereafter ascending to and remaining in a freshwater environment (Figs. 2a,e,i,j, $, 3 a, e, i, j, 1$ \& 4c). This migration pattern is thought to be the major pattern in Rhinogobius sp. BI and is similar to other amphidromous Rhinogobius species, such as Rhinogobius sp. CB (the cross-band type) and Rhinogobius sp. LD (the large dark type) inhabiting mainland Japan (Tsunagawa \& Arai 2008).

Further, some specimens collected downstream of the dam in the Yatsuse River showed different amphidromous migration patterns and could be divided into 3 categories: (1) long marine phase amphidromous (Figs. 2b,f, 3b,f \& 4d); (2) short brackish water phase amphidromous (Figs. 2d,k, 3d,k \& 4b); (3) multiple inter-habitat amphidromous (movement among freshwater, brackish water, and seawater) (Figs. 2c, 3c \& 4e). These migration patterns may be caused by specific environmental conditions in the small oceanic islands, such as flooding after heavy rain, intermittent connection between rivers and sea, and habitat capacity.

In contrast, all samples collected from upriver of the Shigure Dam, an area disconnected both from the downstream area and the sea, indicated that these fish live in freshwater throughout their lives (Figs. $2 \mathrm{~h} \& 3 \mathrm{~h}$ ). Therefore, they are thought to have an artificially landlocked life history (Fig. 4a). This result suggests that an artificial obstacle, such as a dam wall, separating the upstream and downstream areas in rivers makes it more difficult for fish to ascend upstream than if only natural structures, such as waterfalls, were present because all fishes from upstream area of the Tokoyo waterfall exhibited an amphidromous life cycle. There have been similar findings for other amphidromous Rhinogobius species inhabiting Honshu and Shikoku Island in Japan (Tsunagawa \& Arai 2008). Furthermore, similar migration patterns were also found in some specimens from below the dam (Figs. $2 g$ \& 3g). These fish appear to live in a freshwater environment during their whole lives after hatching either upstream or downstream from the dam, although it would be possible for them to move to a downstream area such as marine, brackish environment. Consequently, they are thought to be either an artificially or a naturally landlocked type (Fig. 4a). These results led us to conclude that Rhinogobius sp. BI has a polymorphic migration strategy, allowing it to adapt well to a given artificial or natural environment.

In the present study, the migration histories of the endangered freshwater goby Rhinogobius sp. BI are composed of 5 types: typical amphidromous, long marine phase amphidromous, short brackish water phase amphidromous, artificially or naturally landlocked, and multiple inter-habitat amphidromous types. Although the mechanism of this diverse migratory pattern is still unclear, it may be attributed to genetics or environmental adaptation as in other diadromous fishes (Nordeng 1983, Gross 1985). The Chichijima Island is an oceanic island, and its rivers are extremely small or short and surrounded by a mountainous landmass, so the number and quality of freshwater habitats is limited. Further, Rhinogobius sp. BI habitats are disappearing due to deforestation, topsoil erosion, and artificial river improvements (Suzuki 2003). In addition, deforestation may cause droughts during the dry season and freshets during the rainy season in the river habitat of this species. Thus, as a consequence of artificial environmental changes, Rhinogobius sp. BI might be forced to live in various environments such as freshwater, brackish water, and marine water areas. Further studies are needed to examine the factors affecting the apparently flexible pattern of migration of the species. 
In this context, the detailed migratory histories of the Rhinogobius sp. BI in their entire range should be clarified using otolith microchemistry. Rhinogobius sp. BI is basically amphidromous but may become landlocked when seaward migration is obstructed. These results suggest that this species has a flexible life history strategy which enables them to utilize the full range of salinity in their given environments.

Acknowledgements. We are grateful to Ms. N. Chino and Mr. D. Ueno for their kind assistance with the field survey. The authors thank Ms. M. Otsuki for assistance with the chemical analyses of Ca and Sr. We are also grateful to Ms. T. Mogaki for giving us heartfelt encouragement and support. This work was supported in part by Grants-in-Aid No. 18780141 and 20688008 from the Ministry of Education, Culture, Sports, Science, and Technology of Japan.

\section{LITERATURE CITED}

Akihito, Sakamoto K, Ikeda Y, Iwata A (2000) Gobioidei. In: Nakabo $\mathrm{T}$ (ed) Fishes of Japan with pictorial keys to the species, 2nd edn. Tokai University Press, Tokyo, p 1606-1628

Aonuma Y, Asahida T, Ida H, Iwata A, Kobayashi T (1998) Genetic variation of Rhinogobius fishes (Pisces: Gobiidae) around the East China sea with notes on its zoogeography. DNA Polymorphism 6:116-122

Arai T (2002) Migratory history of fishes: present status and perspectives of the analytical methods. Jpn J Ichthyol 49: $1-23$

Arai T, Otake T, Tsukamoto K (1997) Drastic changes in otolith microstructure and microchemistry accompanying the onset of metamorphosis in the Japanese eel Anguilla japonica. Mar Ecol Prog Ser 161:17-22

Arai T, Kotake A, Lokman PM, Miller MJ, Tsukamoto K (2004) Evidence of different habitat use by New Zealand freshwater eels Anguilla australis and A. dieffenbachii, as revealed by otolith microchemistry. Mar Ecol Prog Ser 266: 213-225

Campana SE (1999) Chemistry and composition of fish otolith: pathways, mechanisms and applications. Mar Ecol Prog Ser 188:263-297

Goto A, Arai T (2003) Migratory histories of three types of Cottus pollux (small-egg, middle-egg and large-egg types), as revealed by otolith microchemistry. Ichthyol Res 50:

Editorial responsibility: Asbjørn Vøllestad, Oslo, Norway
$67-72$

Gross MR (1985) Disruptive selection for alternative life histories in salmon. Nature 313:47-48

Iwata A (1997) Endangered gobies. In: Nagata Y, Hosoya K (eds) Circumstance in endangered Japanese freshwater fishes and their protection. Midori Shobo Press, Tokyo, p 155-164

Kalish JM (1989) Otolith microchemistry: validation of effects of physiology, age and environment on otolith composition. J Exp Mar Biol Ecol 132:151-178

> McDowall RM (1992) Diadromy: origins and definitions of terminology. Copeia 1992:248-251

McDowall RM (1997) Is there such a thing as amphidromy? Micronesica 30:3-14

Ministry of the Environment of Japan (ed) (2003) Threatened wildlife of Japan-Red data book, Vol 4, 2nd edn. Japan Wildlife Research Center, Tokyo

Mizuno N, Tuji K, Suzuki T, Koshikawa T, Iwata A (eds) (2001) Genus Rhinogobius. In: Kawanabe H, Mizuno N, Hosoya K (eds) Freshwater fishes of Japan. Yamatokeikokusha Press, Tokyo, p 584-603 (in Japanese)

> Nordeng H (1983) Solution to the charr problem based on arctic charr (Salvelinus alpinus) in Norway. Can J Fish Aquat Sci 40:1372-1387

> Secor DH, Rooker JR (2000) Is otolith strontium a useful scalar of life cycles in estuarine fishes? Fish Res 46:359-371

> Secor DH, Henderson-Arzapalo A, Piccoli PM (1995) Can otolith microchemistry chart patterns of migration and habitat utilization in anadromous fishes? J Exp Mar Biol Ecol 192:15-33

Senou H, Suzuki T, Shibukawa K, Yano K (eds) (2004) A photographic guide to the gobioid fishes of Japan. Heibonsha, p 445-461, Tokyo

Suzuki T (1992) Rhinogobius sp. BI, a new freshwater goby from Chichi-jima in the Bonin Islands, Japan (Perciformes: Gobiidae: Gobiinae) (preliminary report). Hyogo Freshw Biol 42:5-12

Suzuki T (2003) Rhinogobius sp. 'Ogasawara-Yoshinobori.' In: Ministry of the Environment of Japan (ed) Threatened wildlife of Japan-Red data book, Vol. 4, 2nd edn. Japan Wildlife Research Center, Tokyo, p 134-135

Tsunagawa T, Arai T (2008) Flexible migration of Japanese freshwater gobies Rhinogobius spp. as revealed by otolith Sr:Ca ratios. J Fish Biol 73:2421-2433

Yokoi K, Hosoya K (2003) Distribution and present status of the habitat in Rhinogobius sp. BI (Gobiidae) from the Bonin Islands. Bull Biogeogr Soc Japan 58:1-14

Yokoi K, Hosoya K (2006) Early development of the endangered freshwater goby, Rhinogobius sp. BI (Gobiidae). Ichthyol Res 53:160-165

Submitted: December 19, 2008; Accepted: March 27, 2009

Proofs received from author(s): April 30, 2009 